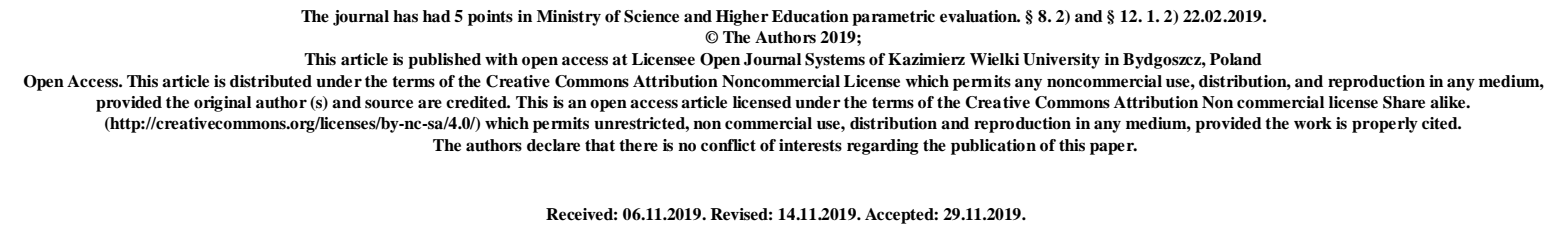

UDC 616-002.2-008.853-092.9:577.114.4

\title{
SUBSTANCE P BLOCKADE EFFECTS ON PERIPHERAL BLOOD LEUKOCYTIC REACTION IN SECONDARY CHRONIC INFLAMMATION
}

\author{
O. M. Shevchenko, V. O. Sych
}

\section{Kharkiv National Medical University, Ukraine}

\section{Abstract}

In an experimental prospective controlled study the leukocyte response of peripheral blood on the background of blockade of receptors of substance $\mathrm{P}$ was studied on the carrageenan model of secondary chronic inflammation in 132 rats. Compared with the natural course of inflammation, at 6 hours there was a significant decrease in total white blood cells count by $1.28(\mathrm{p}<0.05)$, as well as a significant decrease in the number of polymorphonuclear neutrophils by 4 times $(p<0.05)$ and the number of eosinophils by 3 times $(p<0.05)$ by 10 days. On day 28, there was a significant increase in the number of monocytes in 2 times $(\mathrm{p}<0,01)$. The results of the study indicate that in natural conditions of inflammation, substance P stimulates blood leukocytes, as well as prolongs the inflammatory response, and its blocking helps to reduce the inflammatory response.

Key words: secondary chronic inflammation; peripheral blood; substance P; experiment; rats. 


\title{
ЕФЕКТИ БЛОКАДИ РЕЧОВИНИ Р НА ПЕРИФЕРИЧНУ ЛЕЙКОЦИТАРНУ РЕАКЦІЮ КРОВІ ЗА ВТОРИННОГО ХРОНІЧНОГО ЗАПАЛЕННЯ
}

\author{
О. М. Шевченко, В. О. Сич
}

\section{Харківський національний медичний університет, Україна}

В експериментальному проспективному контрольованому дослідженні на карагенановій моделі вторинно хронічного запалення у 132 щурів вивчено лейкоцитарну реакцію периферичної крові на фоні блокади рецепторів субстанції Р. У порівнянні з природнім перебігом запалення, на 6 годину відбувається достовірне зменшення загальної кількості лейкоцитів у 1,28 разів $(\mathrm{p}<0,05)$, а також на 10 добу достовірне зменшення кількості поліморфноядерних нейтрофілів у 4 рази $(\mathrm{p}<0,05)$ та кількості еозинофілів у 3 рази $(\mathrm{p}<0,05)$. На 28 добу спостерігалося достовірне збільшення кількості моноцитів у 2 рази ( $<0,01)$. Результати проведеного дослідження свідчать про те, що в природніх умовах запалення субстанція Р стимулює лейкоцити крові, а також пролонгує запальну реакцію, а іï блокування сприяє скороченню запальної реакції.

Ключові слова: вторинно хронічне запалення; периферична кров; субстанція P; експеримент; щури.

Background. Inflammation is a typical pathological process (a series of sequential intercellular interactions), regulated by modulators of inflammation [1]. Tachykinins are a group of neuropeptides synthesized in almost all parts of the mammalian nervous system and beyond: in the respiratory, cardiovascular, endocrine, digestive and immune systems, as well as in the stroma of the bone marrow and skin [2]. Neuropeptides increase vascular permeability and adhesion of neutrophils to endothelium, increase the sensitivity of nociceptors, participate in the formation of inflammatory pain.

Of considerable interest is the role of tachykinins in the pathogenesis of neurogenic inflammation, which has not been sufficiently studied [3]. Substance P (SP) is one of the most studied tachykinins, which plays a role in the etiology of depression and anxiety, vomiting, pain, asthma, psoriasis, inflammatory bowel disease and central nervous system diseases, including migraine and schizophrenia [4]. Substance P has 2 main types of receptors: neurokinin-1 receptor (NK1R), most of which is on afferent non-myelinated C-fibrils, and ion 
channels transient receptor potential (TRPV1 and TRPA1), represented in the sensory nerves, keratinocytes, mast, dendritic and endothelial cells [5].

A special criterion for the presence of the inflammatory process and the effectiveness of appropriate therapy against it is the cellular dynamics of the inflammatory focus and interrelated changes in the entire blood system, as the blood system is a crucial system of inflammation. Therefore, it is always advisable to study the components of the blood system, and, above all, the leukocyte response of peripheral blood, on the background of blockade of inflammatory mediators.

Thus, the study of the course of inflammation under the conditions of inhibition of substance $\mathrm{P}$ can provide integrative answers to questions about the role and receptor mechanisms of tachykinins in the pathogenesis of inflammation.

Objective: find out the peripheral blood leukocyte reaction in rats at carrageenaninduced chronic inflammation on the background of substance $\mathrm{P}$ inhibition.

Materials and methods of the study: Experiments have been conducted on 132 male rats WAG line with body weight of 180-200 g. Inflammation was initiated by intramuscular injection of $\alpha$-carrageenan solution $-10 \mathrm{mg}\left(« \operatorname{Sigma}{ }^{\circledR} », \mathrm{USA}\right)$ in $1 \mathrm{ml}$ of isotonic sodium chloride [7]. The substance P blocker (inhibitor of NK-1 receptors), aprepitant, $10 \mathrm{mg}$, was administered intraperitoneally dissolved in $1 \mathrm{ml}$ of isotonic sodium chloride daily throughout the experiment [8]. The control group in natural inflammation included intact rats without inflammation, the rats from control group in the series with aprepitant use it was injected without further inflammation modeling. Animals were killed by decapitation under anesthesia at 6 hours, 1st, 2nd, 3rd, 5th, 7th, 10th, 14th, 21st and 28th days of inflammation. Blood was taken from the tail vein before decapitation.

Parametric methods were used in the processing of statistical data, because when assessing the nature of the distribution of quantitative features graphically, it was found that it was close to normal. The description of the central pattern is carried out using mean (M), the variability was characterized by calculating the standard error of mean $(\mathrm{m})$. The probability of differences in the samples by quantitative indicators was calculated using Student's t-test. The threshold value of the significance level $\mathrm{p}$ was chosen to be $0.05,0.01$ and 0.001 .

Processing of the study database, basic calculations of derivative indicators, frequency response of the characteristics, graphing were performed using Microsoft Excel 2019 software, all calculations were performed using Statsoft Statistica 12.0. 
Results. In the natural course of inflammation, there was a tendency to reduce the total number of leukocytes (TLC) in 6 hours by 1.17 times, compared with the control, which is due to the predominance of leukocytes in the inflammatory center over their entry from the bone marrow into the blood (Fig. 1).

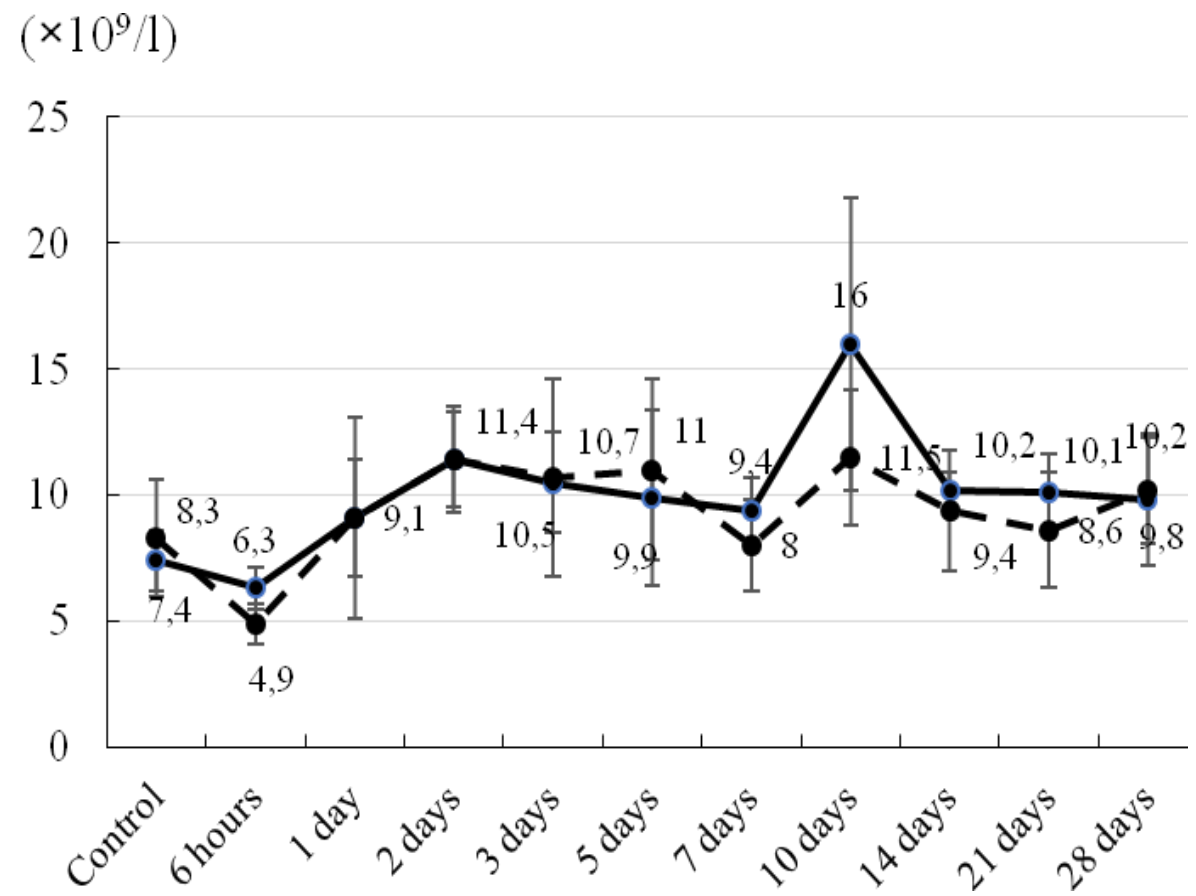

Fig. 1. Total leukocytes count in the peripheral blood of rats $\left(\times 10^{9} / 1\right)$ in the dynamics of the natural course of inflammation (solid line) and on the background of blockade of substance $\mathrm{P}$ receptors (dashed line)

Transient leukopenia may be explained by the known fact that during the inflammatory reaction, the migration of circulating leukocytes in the focus is the most intensive, while the bone marrow does not yet supply a sufficient number of leukocytes [9]. On the 1st day, there is a tendency to increase in TLC, exceeding the control by 1.22 times. There is also a significant increase in TLC compared to the previous period by 1.44 times $(\mathrm{p}<0.05)$. On the 2nd-3rd days, there was a significant increase of TLC in 1.54 times $(\mathrm{p}<0.01)$ and 1.42 times $(\mathrm{p}<0.01)$ respectively, compared with the control. On the 5th day, there is a tendency to increase of TLC, exceeding the control by 1.34 times. From the 7th to the 21 st day there is a significant increase in TLC, with a peak on the 10th day, 1.27 times $(\mathrm{p}<0.05), 2.16$ times $(\mathrm{p}<0.01), 1,38$ times $(\mathrm{p}<0.01), 1.36$ times $(\mathrm{p}<0.01)$ respectively, which corresponds to the second phase of the increase in white blood cells in the blood, and which may indicate a chronic course of inflammation. There is also a significant increase in 
TLC on the 10th day compared to the previous period by 1.7 times $(\mathrm{p}<0.05)$. On 28th day compared with control there was is a tendency to increase of TLC in 1.32 times.

Inflammation on the background of NK1 receptors of substance P blockade in 6 hours was characterized by a significant $(\mathrm{p}<0.05)$ reduction in TLC, 1.69 times compared with the control (Fig. 1). Subsequent changes in the cellular composition of peripheral blood in the blockade of the receptors of substance $\mathrm{P}$ had similar dynamics to those in the natural course of inflammation. On the 1st day, there was a significant $(\mathrm{p}<0.05)$ increase in TLC, 1.85 times compared to the previous period. On the 2nd day, the number of leukocytes significantly increased by 1.37 times $(\mathrm{p}<0.05)$ compared with the control. On the 3rd and 5th day, there was a tendency to increase in the number of inflammatory cells by 1.29 times and 1.32 times, respectively, compared with the control. On the 7th day, we note a tendency to TLC reduce in 1.04 times compared with the control. Of the 10th and 21st days tends to TLC increase was registered compared with control respectively of 1.38 times, 1.13 times and 1.04 times respectively. We also note a significant increase in TLC on the 10th day by 1.43 times $(\mathrm{p}<0.05)$ compared with the previous term. On the 28th day there was a tendency to TLC increase compared to the control by 1.23 times.

At inflammation on the background of the introduction of a receptor blocker of substance $\mathrm{P}$ at the 6th hour the TLC was significantly lower by 1.28 times $(\mathrm{p}<0.05)$ compared with the natural course of inflammation. Subsequent changes in the cellular composition of peripheral blood during blockade of substance P were "wavy" and did not differ significantly from the natural course of inflammation. In the sixth hour, compared to the natural course of inflammation tends to TLC decrease at 1.28 times and 5th day - an increase of TLC at 1.11 times took place. From 7th to 21 th a repeated tends to TLC decrease compared with the same term natural course of inflammation respectively 1.18 times, 1.39 times, 1.08 times and 1.17 times were noted. On the 28th day, on the contrary, compared with the natural course of inflammation, there was a tendency to increase the TLC in 1.04 times.

In the natural course of inflammation in the 6th hour there was a significant increase in the number of segmented neutrophils count $($ SegmNC) in 1.93 times $(\mathrm{p}<0.01)$ compared to controls (Fig. 2). 


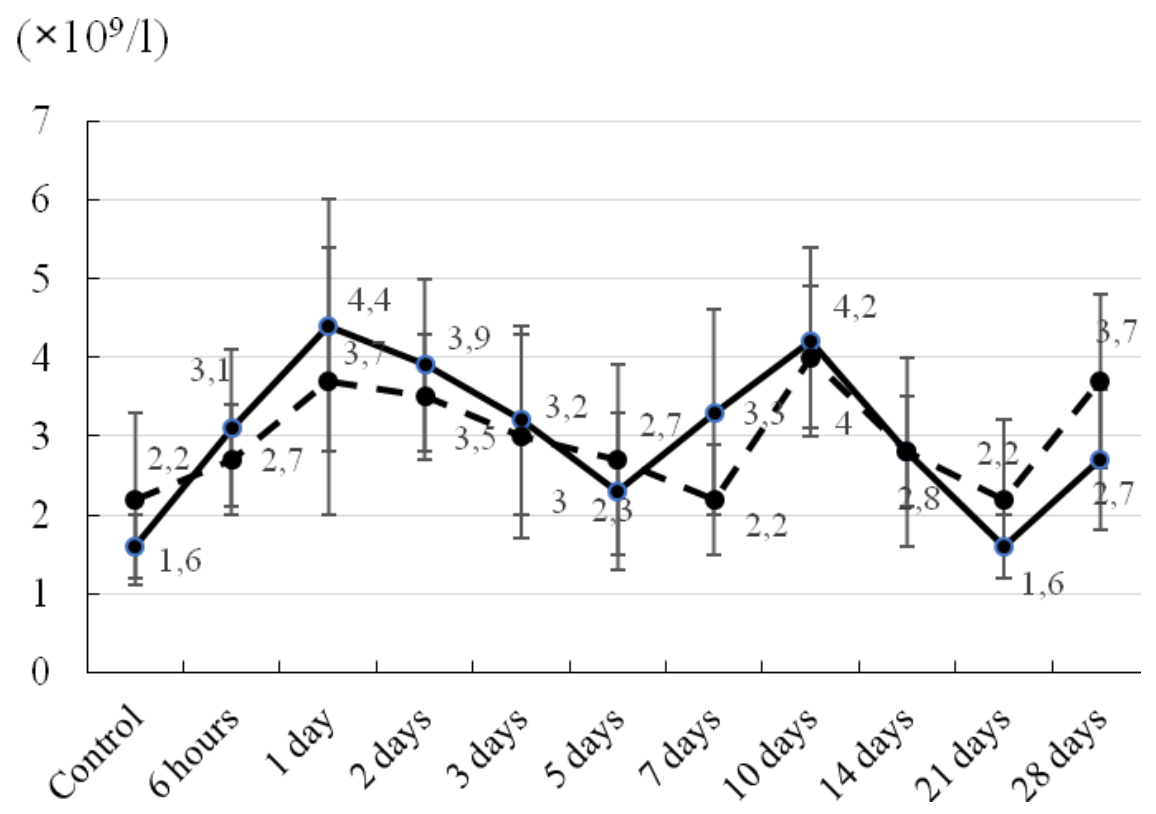

Fig. 2. Segmented neutrophils count in the peripheral blood of rats $\left(\times 10^{9} / 1\right)$ in the dynamics of the natural course of inflammation (solid line) and on the background of blockade of substance $\mathrm{P}$ receptors (dashed line)

On the 1st day, their number reaches a maximum. The SegmNC significantly exceeded the control by 2.75 times $(\mathrm{p}<0.01$ ), which corresponds to the general tendency to leukocytosis in this period. On the 2nd and 3rd days, we observed a significant increase in the number of SegmNC in comparison with the control by 2.44 times $(p<0.001)$ and 2 times $(\mathrm{p}<0.01)$, respectively. On the 5th day, there was a tendency to increase the number of SegmNC compared to the control by 1.44 times. From 7 th to 14 th days a significant increase in the number of SegmNC compared with control respectively in 2.06 times $(p<0.05)$ and 2.62 -fold $(\mathrm{p}<0.001)$ and 1.75 times $(\mathrm{p}<0.01)$ was observed. On the $21 \mathrm{st}$ day, the number of SegmNC significantly decreased compared to the previous period by 1.75 times $(\mathrm{p}<0.05)$, reaching the control value. On the 28th day, the number of SegmNC was significantly increased by 1.69 times $(\mathrm{p}<0.05)$ compared with both the control and the previous term of the experiment.

By the 1st day, on the background of blockade of substance $\mathrm{P}$ in comparison with the control, there is a tendency to increase the number of SegmNC by 1.23 times and 1.68 times, respectively. On the 2nd day, there was a significant increase in the number of SegmNC compared with the control by 1.59 times ( $\mathrm{p}<0.05)$. On the $3 \mathrm{rd}$ day of the experiment, there is a tendency to increase the number of SegmNC in 1.36 times compared with the control. After 
5th day a significant increase in the number of SegmNC compared with control at 1.23 times $(\mathrm{p}<0.05)$ was registered. On the 7th day, the number of neutrophils corresponds to the control value, and on the 10th day there is a peak in the number of SegmNC, which significantly exceeds the control value by 1.82 times $(\mathrm{p}<0.05)$, as well as the value of the previous term by 1.82 times $(\mathrm{p}<0.01)$. On the 14th and 28th day, compared to the control, there was a tendency to increase in the number of SegmNC in 1.27 times and in 1.68 times, respectively.

In the blockade of substance $\mathrm{P}$ the SegmNC was not significantly different from the natural course of inflammation and there wavy tendency to reduce the number of SegmNC compared to the natural course of inflammation in 6 hours and in 1, 2, 3 days - 1.15 times, 1.19 times, 1.11 times and 1.07 times accordingly, and the tendency to increase their number on the 5th day by 1.17 times took place. On the 7 th and 10th day, compared with the natural course of inflammation, there was again a tendency to reduce the number of SegmNC in 1.5 times and 1.05 times, respectively. On the 21 st and 28th day, compared to the natural course of inflammation, there was a tendency to increase the SegmNC in 1.37 times .

In the natural course of inflammation compared with the control on the $6^{\text {th }}$ hour there was a tendency to reduce the number of stab neutrophils count (StabNC) in 2 times (Fig. 3).

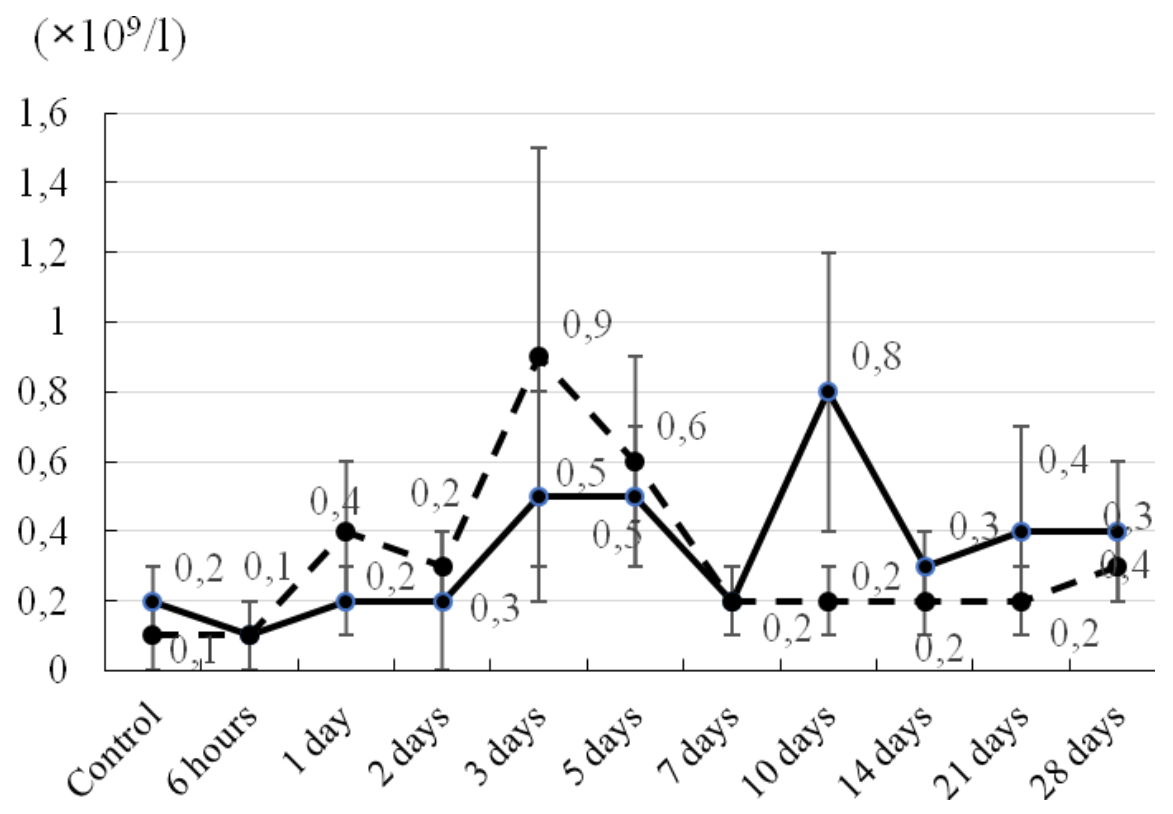

Fig. 3. Stab neutrophils count in the peripheral blood of rats $\left(\times 10^{9} / 1\right)$ in the dynamics of the natural course of inflammation (solid line) and on the background of blockade of substance $\mathrm{P}$ receptors (dashed line) 
On the 3rd and 5th day, compared with the control, the amount of StabNC significantly increased in 2.5 times $(\mathrm{p}<0.05)$. On the 7 th day there was a tendency to return the amount of StabNC to the control value. On the 10th day there was a peak in the amount of StabNC, which significantly, 4 times $(\mathrm{p}<0.01)$, exceeded the value of control. Also on the 10th day compared to the previous period of inflammation, the amount of StabNC was significantly increased 4 times $(\mathrm{p}<0.05)$. On the 14 th and 21 st day, compared with the control, we noted a repeated tendency to increase the number of StabNC in 1.5 times and 2 times, respectively. Also on the 14th day in comparison with the previous term there was a significant decrease in the amount of StabNC in 2.67 times $(p<0.05)$. On the 28th day, compared with the control, the amount of StabNC remained significantly increased by 2 times $(\mathrm{p}<0.05)$.

In inflammation on the background of blockade of substance $\mathrm{P}$ on the 1st day, the amount of StabNC in the blood significantly increased 4 times $(\mathrm{p}<0.05)$. Also on the 1 st day the amount of StabNC compared to the previous term was significantly increased 4 times $(\mathrm{p}<0.01)$. From 2 nd to 5 th day compared with control a significant increase in StabNC 3 times ( $\mathrm{p}<0.05), 9$ times $(\mathrm{p}<0.05)$ and 6 times $(\mathrm{p}<0.05)$ was revealed. Also on the 3rd day compared to the previous term, the amount of StabNC was significantly increased 3 times $(\mathrm{p}<0.05)$. From 7 th to 21 th compared with control a tendency to increase the StabNC in 2 times was observed. On the 7th day compared to the previous period, we noted a significant decrease in the amount of StabNC in 3 times $(\mathrm{p}<0,05)$. On the 28th day, compared to the control, there was a tendency to increase the number of StabNC by 3 times.

In inflammation on the background of the blockade of substance $\mathrm{P}$ compared to the natural course of inflammation StabNC on the first day was significantly increased in 2 times and $(\mathrm{p}<0.05)$ and in 10 days - it was significantly 4-fold decreased $(\mathrm{p}<0.05)$. On the 2nd, 3rd, 5th days in comparison with the natural course of inflammation we noted a tendency to increase in the number of StabNC in 1.5 times, 1.8 times and 1.2 times, respectively, and on the 14 th, 21 st and the 28 th day - the tendency to their reduction respectively 1.5 times, 1.3 times and 2 times.

In the natural course of inflammation on the 1 st day there was a tendency to increase in the number of eosinophils (in 3 times compared with the control (Fig. 4). 


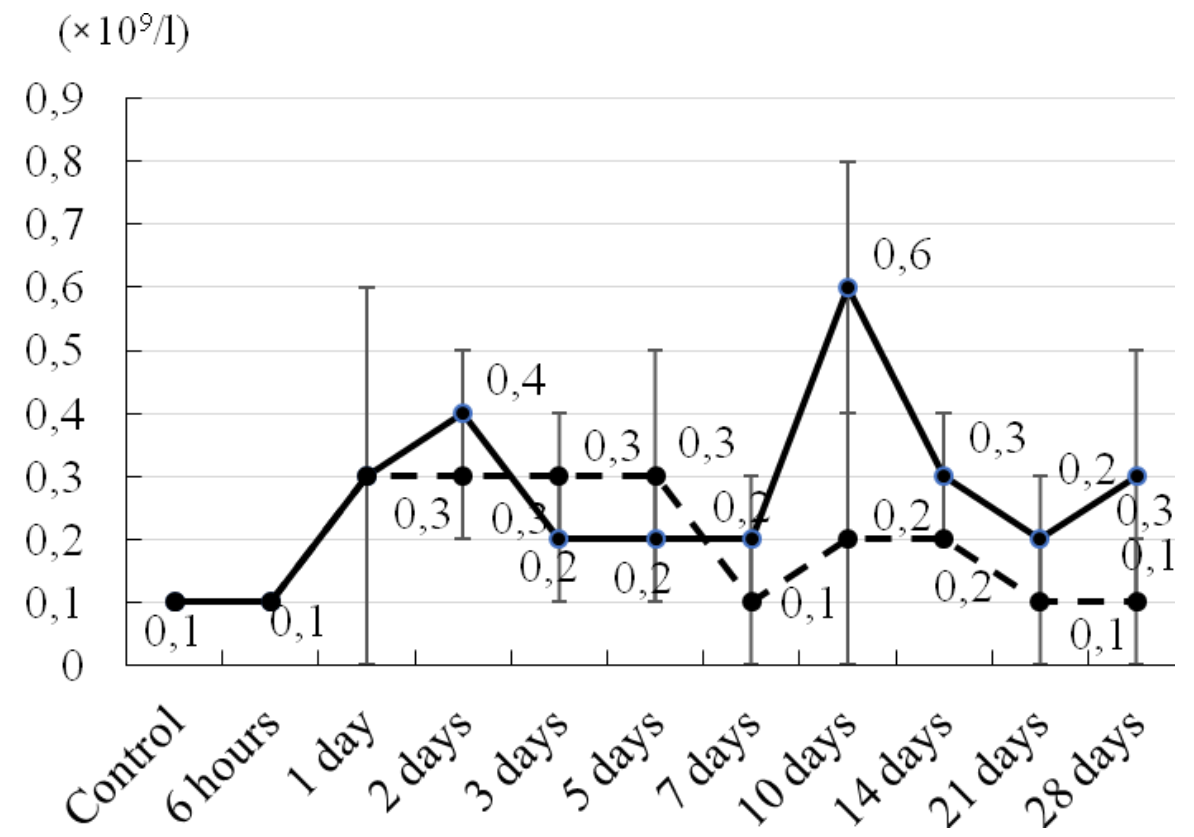

Fig. 4. Eosinophils count in the peripheral blood of rats $\left(\times 10^{9} / 1\right)$ in the dynamics of the natural course of inflammation (solid line) and on the background of blockade of substance P receptors (dashed line)

On the 2nd day we noted a significant increase in the number of eosinophils in 4 times ( $\mathrm{p}<0,001)$ compared with the control. On the 3rd day there was a tendency to increase in the number of eosinophils in 2 times compared to the control and a significant decrease in their number in 2 times $(\mathrm{p}<0,01)$ compared to the previous term. On the 5th and 7th day compared with the control there was a significant increase in the number of eosinophils in 2 times $(\mathrm{p}<0,05)$, on the 10th day - in 6 times $(\mathrm{p}<0,001)$, on the 14th day - in 3 times $(\mathrm{p}<0.01)$, on the 21 st day - in 2 times $(\mathrm{p}<0.05)$ and on the 28th day - in 3 times $(\mathrm{p}<0.05)$. Also on the 10th day compared with the previous term there was a significant increase in the number of eosinophils in 3 times $(\mathrm{p}<0,01)$.

At blockade of substance $\mathrm{P}$ on the 1st day in comparison with control the tendency to increase in number of eosinophils in 3 times is observed. From the 2 nd to the 5 th day, compared with the control, there was a significant increase in the number of eosinophils in 3 times $(\mathrm{p}<0.05)$, and on the 7 th day the indicator significantly corresponded to the control values $(\mathrm{p}<0.05)$. On the 10th day, there was a tendency to increase in the number of eosinophils in 2 times compared with the control.

On the background of the introduction of a blocker of receptors of substance $\mathrm{P}$ compared with the natural course of inflammation, the number of eosinophils on the 10th day 
was significantly reduced by 3 times $(\mathrm{p}<0.05)$. At other times there were no significant differences from the natural course of inflammation. However, the tendency to increase in the number of eosinophils was observed only on the 3rd and 5th days by 1.5 times, and at other times there was a wavy tendency to decrease in their number compared to the natural course of inflammation: on the 3rd day - at 1.5 times, on the 7th, 14th and 21st day -2 times, on the 28 th day -3 times.

In the natural course of inflammation at 6 hours, compared with the control, there was a tendency to reduce the number of monocytes by 1.5 times (Fig. 5).

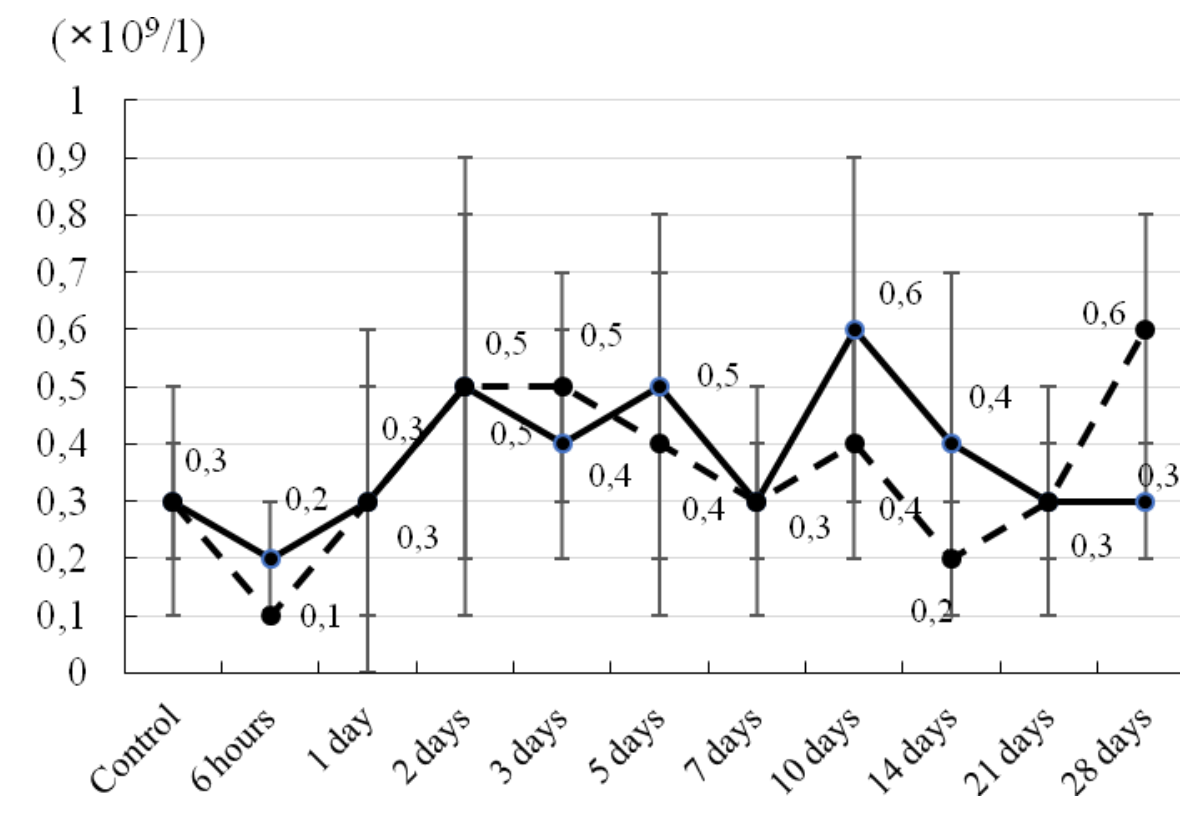

Fig. 5. Monocytes count in the peripheral blood of rats $\left(\times 10^{9} / 1\right)$ in the dynamics of the natural course of inflammation (solid line) and on the background of blockade of substance $\mathrm{P}$ receptors (dashed line)

From the 2nd to the 5th day, compared with the control, we noted a tendency to increase in the number of monocytes by 1.66 times, 1.33 times and 1.66 times, respectively. On the 10th day, the number of monocytes significantly exceeded the control by 6 times $(\mathrm{p}<0.05)$. Also, on the 10th day in comparison with the previous term we noted a significant increase in the number of monocytes in 2 times $(p<0,05)$. On the 14th day, compared with the control, there was a tendency to increase the number of monocytes by 1.33 times, and on the 21 st and 28th day, the indicator corresponds to the control value.

In the receptors of substance $\mathrm{P}$ blockade compared to the natural course of inflammation on the 28th day a reliable increase in the number of monocytes in the blood of 
rats 2 times $(\mathrm{p}<0.05)$ was observed. In other terms notes only undulating trend to fewer monocytes in 6 hours, 5th, 10th and 14th day respectively 2 times, 1.25 times, 1.5 times and 2 times, and the trend to increase in their number - on the 3rd day by 1.25 times.

In the natural course of inflammation on the 6th hour compared to the control lymphocytes count in the blood was significantly reduced and in 1.89 times $(\mathrm{p}<0.01)$ (Fig. 6).

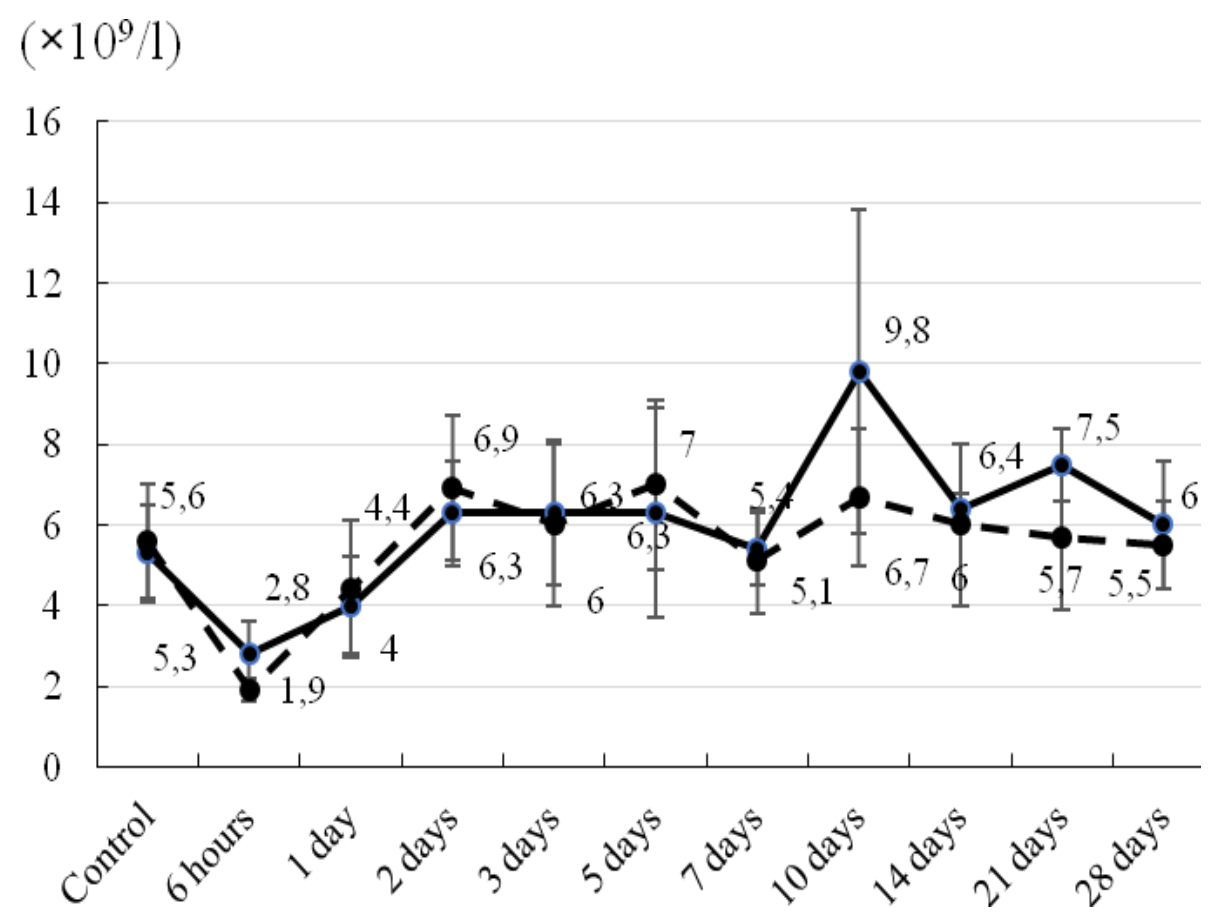

Fig. 6. Lymphocytes count in the peripheral blood of rats $\left(\times 10^{9} / 1\right)$ in the dynamics of the natural course of inflammation (solid line) and on the background of blockade of substance P receptors (dashed line)

On the 1st day, compared with the control, there was a tendency to decrease of them by 1.1 times, and during the 2 nd -5 th days - to increase by 1.19 times. At the same time on the 2 nd day the number of lymphocytes significantly exceeded the value of the previous term by 1.57 times $(\mathrm{p}<0,01)$. On the 10th day, compared with the control, there was a tendency to increase in the number of lymphocytes in 1.02 times, and on the 10th day we noted the peak of the lymphocytic reaction, which significantly exceeded 1.85 times $(\mathrm{p}<0.05)$ in 1.81 times $(\mathrm{p}<0.05)$ comparing with the previous term. On the 14th day compared with the control there was a tendency to increase in the number of lymphocytes by 1.2 times, and on the 21 st day we noted a significant increase in the number of lymphocytes by 1.41 times $(p<0.01)$ compared with the control. In addition, the number of lymphocytes was significantly increased by 1.17 times $(\mathrm{p}<0.05)$ by $21 \mathrm{st}$ day in comparison with the previous term. On the 28th day, 
compared with the control, there was a tendency to increase the number of lymphocytes by 1.13 times.

In the blockade of substance $\mathrm{P}$ receptor on the sixth hour, compared to the control, a significant reducing in the number of lymphocytes in 2.94 times $(\mathrm{p}<0.001)$ was observed. On the 1st day compared with the control we noted a tendency to decrease in the number of lymphocytes in 1.27 times, and then from the 2 nd to the 7 th day - a tendency to increase in their number, respectively, in 1.23 times, in 1.07 times, 1.25 times. In addition, the number of lymphocytes was significantly higher than the value in previous time in on the 1 st day in 2.31 times ( $\mathrm{p}<0.01)$, and on the 2 nd day - in 1.57 times $(\mathrm{p}<0.05)$. On the 7 th day in comparison with the control there was a repeated tendency to decrease in the number of lymphocytes by 1.10 times, and from the 10th to the $21 \mathrm{st}$ day - a repeated tendency to increase in their number by 1.2 times, 1.07 times and 1.02 times.

At blockade of NK1 receptors of substance P in comparison with a natural course of inflammation no significant differences in number of lymphocytes was observed, however quantitatively lymphocytic inflammation was less expressed. Throughout the experiment, compared with the natural course of inflammation, there was a wavy tendency to decrease in the number of lymphocytes at 6 hours -2.1 times, on the 3rd day - 1.05 times, and a tendency to increase their number by 1 day -1.1 times, on the 2 nd day -1.09 times and on the 5 th day -1.11 times. From the 7 th to the 28th day, compared with the natural course of inflammation, there was a repeated tendency to reduce the number of lymphocytes in 1.06 times, 1.46 times, 1.07 times, 1.32 times and 1.09 times, respectively.

Thus, with inflammation on the background of blockade of substance $\mathrm{P}$ neurokinin receptors type 1 - in 6 hours there is a significant decrease in total leukocyte count, 1.28 times ( $\mathrm{p}<0,05)$, as well as on the 10th day; a significant decrease in the number of stub neutrophils in 4 times $(p<0.05)$ and the in the number of eosinophils in 3 times $(p<0.05)$. These changes are probably related to the fact that in an activation of specific NK1R in bone marrow, substance P stimulates the production of granulocyte-macrophage colony stimulating factor and iterleukin 3, causing proliferation of hematopoietic cells [10]. This fact is confirmed by in vitro studies, in which under the influence of substance $\mathrm{P}$ there was a proliferation of stromal cells of the bone marrow and the formation of new myeloid and erythroid colonies [11]. In addition, substance P stimulates sympathetic peptidergic nerve endings, which are also found in the bone marrow in close proximity to hematopoietic cells. Therefore, the blockade of NK1 receptors of substance $\mathrm{P}$ reduces the activation of hematopoiesis and new populations of myeloid cells do not enter the peripheral circulation, 
thereby reducing the inflammatory response. Deletion of Tacr1 gene, responsible for the expression of NK1R, leds to a deficit of precursor B- and T-lymphocytes, although in the same experiment substance $\mathrm{P}$ deficiency has less impact on the recovery of erytromyeloid cells, indicating a paracrine or endocrine mechanism of action of tachykinins [12]. Although in our study with blockade of substance $\mathrm{P}$ the number of lymphocytes in the blood did not significantly differ from the natural course of inflammation, there was a tendency to reduce in their number after 6 hours and from 7 days to the end of the study compared to the same timing of natural inflammation. At the same time, in our study on day 28 there was an increase in the number of monocytes in 2 times $(\mathrm{p}<0,01)$ compared with the same period of the natural course of inflammation. This may be due to participation of substance $\mathrm{P}$ in an increase of secretion of monocytes chemotaxis factor 1 that promotes migration of monocytes, macrophages and NK-cells into inflammatory focus [13]. Accordingly, when the substance $\mathrm{P}$ is blocked, the migration of monocytes into the inflammatory cell decreases, and their number in the peripheral blood increases.

The results of the study indicate that in conditions of inflammation, substance $\mathrm{P}$ stimulates blood leukocytes, as well as prolongs the inflammatory response.

\section{Conclusions}

1. In conditions of inflammation, substance $\mathrm{P}$ blockage diminishes the intensity of blood leukocytes activation, and shortens the inflammatory response.

2. The peripheral blood leukocyte reaction in rats at carrageenan-induced chronic inflammation on the background of substance $\mathrm{P}$ inhibition is characterized by significant decrease in total leukocyte count, stub neutrophils and eosinophils in 6 hours, 10 days; significant increase in the number of monocytes on 28th day, comparing with natural course of inflammation.

3. Prospects of further research concern an integral evaluation of bone marrow, tissuecellular reactions in situ, peripheral blood, cytokines and other markers of inflammation on the background of substance $\mathrm{P}$ blockage.

\section{References}

1. Markers of Inflammation / D. R. Germolec, K. A. Shipkowski, R. P. Frawley, E. Evans // Methods Mol Biol. — 2018. — Vol. 1803. - P. 57-79. - DOI: 10.1007/978-14939-8549-4_5

2. Tachykinins and tachykinin receptors: a growing family / J. N. Pennefather, A. Lecci, M. L. Candenas [et al.] // Life Sci. — 2004. - Vol. 74, No. 12. — P. 1445-1663. — DOI: doi: 10.1016/j.lfs.2003.09.039 
3. Immune cytokines and their receptors in inflammatory pain / A. D. Cook, A. D. Christensen, D. Tewari [et al.] // Trends Immunol. — 2018. - Vol. 39, No. 3. - P. 240-255. — doi: 10.1016/j.it.2017.12.003

4. Majkowska-Pilip A. The Significance of NK1 Receptor Ligands and Their Application in Targeted Radionuclide Tumour Therapy / A. Majkowska-Pilip, P. K. Halik, E. Gniazdowska // Pharmaceutics. - 2019. - Vol. 11, No. 9. - pii: E443. - DOI: 10.3390/pharmaceutics11090443

5. Mantyh P. W. Neurobiology of substance P and the NK1 receptor / J. Clin. Psychiatry // 2002. — Vol. 63, Suppl. 11. — P. 6-10. — PMID: 12562137

6. Efficacy and safety of aprepitant in combination with dexamethasone, granisetron and metoclopramide as a prophylaxis of chemotherapy-induced nausea and vomiting in an acute and delayed emesis in arab cancer patient / M. Iman, O. Frasia, B. M. Essam // Cancer Med. Anticancer Drug. - 2017. — Vol. 2, No. 1. - 100107. - DOI: 10.4172/25761447.1000107

7. Klymenko N. A. Substantiation of the model of chronic (secondary) inflammation / N. A. Klymenko, S. V. Tatarko, A. N. Shevchenko [et al.] // Experimental and Clinical Medicine. - 2007. - No. 2. - P. 12-17.

8. An FDA approved neurokinin-1 receptor antagonist is effective in reducing intraabdominal adhesions when administered intraperitoneally, but not orally / R. Lim, J. M. Morrill, S. G. Prushik [et al.] // J. Gastrointest. Surg. — 2008. — Vol. 12. — P. 1754-1761. — DOI: 10.1007/s11605-008-0634-4.

9. Klymenko N. A. Hematologic mechanisms of inflammation chronization / N. A. Klymenko, A. N. Shevchenko. - Kharkiv, 2010. - 88 p.

10. Inflammation in acute CNS injury: a focus on the role of substance P / F. Corrigan, R. Vink, R. J. Turner // Br. J. Pharmacol. — 2016. — Vol. 173, No. 4. - P. 703715. — DOI: 10.1111/bph.13155

11. Neurological regulation of the bone marrow niche / F. Aerts-Kaya, B. Ulum, A. Mammadova [et al.] // Adv. Exp. Med. Biol. — 2019. — doi: 10.1007/5584_2019_398.

12. Neurokinin-1 receptor signalling impacts bone marrow repopulation efficiency / A. Berger, C. Frelin, D. K. Shah [et al.] // PLoS One. - 2013. - Vol. 8, No. 3. - e58787doi: 10.1371/journal.pone.0058787. 
13. Substance $\mathrm{P}$ promotes wound healing in diabetes by modulating inflammation and macrophage phenotype / E. C. Leal, E. Carvalho, A. Tellechea [et al.] // Am. J. Pathol. Jun. 2015. — Vol. 185, No. 6. - P. 1638 - 1648. — DOI: 10.1016/j.ajpath.2015.02.011 